to English literature of all periods, but which are also strong on subjects that fall into the framework of British civilization and institutions. In science, medicine and technology the tendency is to concentrate wholly on those aspects in which the British contribution has special significance for the country concerned. Expenditure on the purchase of books has fallen from $£ 81,000$ in 1947-48 to less than $£ 20,000$ in 1951-52, and of the latter sum only $£ 1,500$ was for books presented to other libraries (virtually all in the Colonial territories) compared with $£ 19,000$ in 1947-48, of which more than a half was for foreign countries. The scope of the Council's library activities in the Colonies has been restricted since 1948 , but the report comments on the difficulty of keeping libraries supplied with new books on a budget a quarter of its size five years ago and with prices rising steeply : gaps left by years of scarcity are for the most part unfilled. Statistics for the stock, issues and membership of the Council's libraries are appended to the report. There are some remarkable variations in the ratio of book stock to monthly issues. Rio de Janeiro and Cairo, each with approximately 21,000 volumes, have monthly issues of 165 and 1,600 , respectively. Ibadan and Zagreb issue 1,275 and 1,118 volumes monthly out of a stock of 3,000 , while Barcelona issues 4,207 volumes monthly out of 10,000, Bandung (Indonesia) 2,124 out of a stock of 6,000, and Madras 1,709 out of 3,800. Only 44 out of Nairobi's 1,500 volumes, and 60 out of Blantyre's 1,200 volumes are issued monthly; there would seem to be room for some inquiry as to whether all the libraries are worth maintaining and whether the resources of others should be extended.

\section{NEW ZEALAND DEPARTMENT OF SCIENTIFIC AND INDUSTRIAL RESEARCH}

\section{REPORT FOR THE YEAR 1951-52}

\begin{abstract}
THE twenty-sixth annual report* of the Department of Scientific and Industrial Research, New Zealand, covers the year ended March 31, 1952, during which no expansion of activities was possible and those of many branches were curtailed in consequence of a restriction in the financial vote. Net expenditure for the year was $£ 1,036,581$, and, while the recruitment of scientific staff was exceptionally low, losses of experienced staff were high, although partly offset by the return from overseas of men who had completed advanced studies in various fields. The total staff on March 31, 1952, was 1,012, including 402 professional and 354 technical workers. Achievements of the year stressed in the secretary's report include the completion of geological surveys of the four main coalfields; very extensive coal-measures found in the Kaitangata field are of special interest. Surveys in North Auckland have indicated the rock formations associated with good and bad prospects for securing water supplies for farm purposes, while geological and geophysical investigations have located a hot area at Wairakei sufficiently promising for the inauguration of a development programme to prove the existence of a steam potential capable of gener-

* New Zealand. Twenty-sixth Annual Report of the Tenartment of Scientific and Industrial Research. Pp. 84. (Wellington: Govt.
\end{abstract} Printer, 1952.) 18. 9d. ating $20,000 \mathrm{~kW}$. Chemical investigations indicate that the steam has a low content of gas and is free from corrosive properties. An efficient geothermograph has been designed and constructed to measure temperatures at depth in bores.

Research on spontaneous combustion in wool cargoes indicates that the fires are confined to wools removed from skins by a bacterial process. These often contain a high percentage of body fat, and this potential source of danger can at present only be overcome by a very thorough scouring of the wool. The solution of this problem would save thousands of pounds annually. Following the discovery of the causal agents of the yellow-leaf disease of Phormium, it has now been found that the insect vector may be killed in all its stages by flooding areas growing New Zealand flax to a depth of two to three feet for fourteen days. Yellow-leaf disease has halved the production of flax fibre since 1938, and this advance promises to save almost the whole industry.

The nutritional value of the branched-ehain acids discovered earlier in butter-fat is now being investigated, and accurate information on the changes in butter-fat composition that occur during the season has been obtained for the first time. A system for the certification of plant hormone sprays, based on the experimental work of the past few years, has now been established and is regarded as of considerable economic importance both in protecting growers from losses incurred in misapplication and in assisting manufacturers in production. Broad correlations revealed between soil types and tree-growth characteristics in soil surveys of the Kaingaroa Plains are expected to assist the State Forest Service in its development of the timber resources of this area as well as timber production, management and utilization elsewhere. The efficiency of boric acid in controlling Ambeodentus, the New Zealand wood-boring insect second in importance to Anobium, was proved during the year, and New Zealand timbers used for building and furniture can now be proofed against the three prevalent boring insects by treatment with boric acid.

In the tobacco industry use of methyl bromide as a soil sterilizer in seedling beds appears likely to supplant to a large extent the present costly and cumbersome steam sterilization operation. Striking results have been obtained in reducing the growth of laterals when tobacco plants have been topped by spraying the upper leaves with certain chemicals such as maleic hydrazide and mineral oil. Both discoveries promise considerable savings to the tobacco industry, while a new sample survey method of collecting agricultural and pastoral statistics designed by the Applied Mathematics Laboratory is expected to reduce markedly the costs incurred by the Census and Statistics Department in collecting this information. Investigations in the Dominion Physical Laboratory of a number of enclosed domestic stoves burning solid New Zealand fuels have shown that efficiencies of 45 to more than 70 per cent can be obtained, with proper design and control, compared with 10-15 per cent with the ordinary open-hearth fire. Since the cost installed does not exceed that of the ordinary chimney and grate, considerable savings should be possible in the use of coal for domestic heating. Radioactive cobalt and iridium have been used in the X-ray examination of welded metals and castings and in testing steel conduits for hydroelectrical installations. Further work by the Leather 
and Shoe Research Association on the modification of New Zealand fish liver oils for the production of chamois leather has yielded a process for utilizing vegetable oils in oil-tanning which, besides producing stronger leather, enables white washable gloving leather to be obtained without bleaching. Bark from Pinus radiata has been proved to be a possible source of tannin, and the detrimental effect of high temperatures upon pickled pelts in storage and transport has been demonstrated. The investigations by the Pottery and Ceramics Research Association indicate that for ceramic manufacture deposits of ball clays from Canterbury, Otago and Southland are equal in quality to any such deposits found elsewhere in the world.

\section{OCEANOGRAPHY IN THE UNITED STATES}

IN 1927 the United States National Academy of Sciences appointed a Committee to consider the share of the United States in a world-wide programme of oceanographical research. Much of the Committee's report was published in book form under the title "Oceanography : Its Scope, Problems and Economic Importance", by Henry B. Bigelow (1931). One of the major outcomes of the decisions of that Committee was the building and endowment of the Oceanographic Institution at Woods Hole, and there was a general all-round increase in marine research.

In 1949 a second Committee on Oceanography was established by the National Academy. The reason for the setting up of this second body was not lack of interest in oceanography. Owing to the recognition of the practical applications of oceanography during the Second World War, marine research had, in fact, flourished; but it was chiefly government sponsored. As a result of inflation and the heavy cost of maintenance of modern research ships and equipment, private endowments were entirely inadequate, and research could only continue at its present scale with heavy government support. The Committee considered that "the healthy growth of oceanography has been hampered by the uncertainty as to how long this support may be available, and by other restrictions". It was to report on this situation that the Committee was appointed. Its report, entitled "Oceanography 1951", is now published".

As in the previous report, the relations of the science to biology, geology and meteorology, and certain recent notable advances, are surveyed. The advance in physical oeeanography has been very striking. That this is so is largely due to the War, which has resulted in the provision of "a nucleus of 80 to 100 physical oceanographers in this country, compared with perhaps half a dozen prior to 1930 . ... More than half of the funds being expended for oceanographic investigations at the present time come from the Department of Defence".

The sea is a source of food, and it is necessary to ensure that research is also directed towards increasing the yield from the sea fisheries, as well as gaining knowledge useful in war. The annual yield of the

- National Academy of Sciences-National Research Council. Pub llention 208: Oceanography 1951; a Keport on the Present Status of the Science of the Sea by the Committee on Oceanography of the National Academy of Sciences. Pp. vil +36 . (Washington, D.C. National Academy of Sclences-National Research Council, 1952.) world's fisheries is quoted as twenty million tons, giving only one-fiftieth of the total protein consumption, yet half the world's population has a diet seriously deficient in protein. The Committee considers that "Heretofore most fishery research programmes were attempted on too small a scale. This was due to lack of appreciation of the complexity and magnitude of fishery problems, so that insufficient funds were assigned to many projects". Recently, however, there have been large-scale attacks on certain problems, such as the causes of the disappearance of the Californian sardine; the potentialities of the pelagic fisheries of the central North Pacific; and the movements of the Gulf Stream.

But the Committee considers that oceanography is not developing in a well-balanced manner and that there is almost no financial support for general marine biology. It thinks that inadequate attention is being paid to many challenging problems which do not have military significance and do not bear on specific fisheries ; and it feels that, in order to ensure more freedom of research into such basic problems, greater private financial support is needed. At the same time, government support on a liberal and far-sighted basis should be continued, to provide the large-scale co-ordinated effort which the size and complexity of oceanic phenomena demand. Through the United Nations and President Truman's Point Four Programme, the United States should also encourage the development of oceanography in other countries, and especially in the southern hemisphere and western Pacific. The Committee recommends the securing of private funds for the provision of research fellowships at existing nceanographic institutions; for facilities for visiting investigators ; for the provision of more permanent posts ; and to supply increased funds for operating ships and for basic research in biology and chemistry.

The present total income of institutions in the United States carrying out oceanographical research is about 2,300,000 dollars, four-fifths of which is supplied by the government. It is recommended that the additional funds from private sources should be between 500,000 and 750,000 dollars. This would bring the total annual expenditure on oceanographical research into the region of one million pounds sterling by those laboratories other than the Federal and State organizations.

F. S. Russell

\section{PRESERVATION OF THE LAKE DISTRICT}

$\mathrm{T}$ HE Report and News Letter for August of the Friends of the Lake District* records a discouraging year, and refers particularly to the absence of a Joint Planning Board except in name for the Lake District National Park and to the hobbling of that authority by the failure to appoint a planning officer for the Park. The practical consequences of this position are concisely and clearly indicated, as well as the requirements for the effective functioning of any joint board. Local matters on which the Report and News Letter comment are the assurance received from the superintendent of the Eskmeals military range that the proposed night firing is, in

- Friends of the Take District. Report and News Letter, August. Pp. 20. (14 Princes Street, Ulverston, 1952.) 